http://dx.doi.org/10.11646/phytotaxa.76.3.6

\title{
Notes on Early Land Plants Today. 18. Transfers of some taxa in Nardia (Gymnomitriaceae, Marchantiophyta)
}

\author{
JIŘÍ VÁŇA ${ }^{1}$, LARS SÖDERSTRÖM ${ }^{2,4}$, ANDERS HAGBORG ${ }^{3}$ \& MATT VON KONRAT $^{3}$ \\ ${ }^{1}$ Department of Botany, Charles University, Benátská 2, CZ-12801 Praha 2, Czech Republic; vana@natur.cuni.cz \\ ${ }^{2}$ Department of Biology, Norwegian University of Science and Technology, N-7491 Trondheim, Norway; lars.soderstrom@bio.ntnu.no \\ ${ }^{3}$ Department of Botany, The Field Museum, 1400 South Lake Shore Drive, Chicago, IL 60605-2496, USA; hagborg@pobox.com, \\ mvonkonrat@fieldmuseum.org \\ ${ }^{4}$ Author for correspondence
}

In recent years, molecular studies have shown that characters associated with reproduction (sexual as well as asexual) are much more important in separating taxa at higher level than generally believed 10-15 years ago. For example, the color of gemmae (red or yellow) is a character separating Lophozia (Dumortier 1831: 53) Dumortier (1835: 17) s.str. from Lophoziopsis Konstantinova \& Vilnet (2010: 66) (De Roo et al. 2007, Vilnet et al. 2011). Also, the presence and absence of a perigynium is shown to separate the two genera Jungermannia Linnaeus (1753: 1131) and Solenostoma Mitten (1865: 51), two genera that have mostly been treated as congeneric over the last 25-30 years (see Váňa \& Long 2009).

Both Nardia scalaris Gray (1821: 694) and Nardia geoscyphus (De Notaris 1858: 486) Lindberg (1874: 371) occur with two types of perigynium. The main form of Nardia geoscyphus has the Nardia geoscyphustype perigynium. However, there are also specimens with an Isotachis-type perigynium. Those plants correspond to "var. suberecta" (cf. Váňa 1976 who regarded them as synonyms of Nardia geoscyphus).

Nardia scalaris has predominantly Isotachis-type perigynium but plants from Japan with Nardia geoscyphus-type of perigynium are described as Nardia scalaris subsp. harae.

Until the differences in perianth type have been studied in more detail, preferably including molecular studies, we think a variety of each species could be recognized. Unfortunately, none of the taxa have been combined at variety level.

Schuster (1969) described Nardia scalaris subsp. botryoidea from three widely separated localities in North America based mainly on differences in the shape of the oil bodies compared to subsp. scalaris. The subspecies has not received much attention since then. Until the variation of oil bodies in Nardia scalaris is re-studied we prefer to treat it as a variety.

\section{Formal treatment}

The format of this note follows what is outlined in Söderström et al. (2012).

Nardia geoscyphus var. suberecta (Lindb. ex Kaal.) Váňa, comb. nov. [C. Massal. et Carestia, Nuovo Giorn. Bot. Ital. 14: 223, 1882, unranked and nom. inval. (Art. 32.1.d; no description)].

Basionym:-Nardia haematosticta var. $\beta$ suberecta Lindb. ex Kaal., Nyt Mag. Naturvidensk. 33: 395 , 1893 (Kaalaas 1893).

Lectotype (Ván̆a 1976):-FINLAND. Kajana: Karanke, 1872 Lackström (H-SOL!). 
Nardia scalaris var. harae (Amakawa) Váňa, comb. et stat. nov.

Basionym:-Nardia harae Amakawa, J. Jap. Bot. 32: 38, 1957 (Amakawa 1957).

Type:-JAPAN. Ehime Pref.: Mt. Izishizuchi, 1790 m alt., 6 June 1952, M. Hara 6101 (holotype NICH).

$\equiv$ Nardia scalaris subsp. harae (Amakawa) Amakawa, J. Hattori Bot. Lab. 21: 280, 1959 (Amakawa 1959).

Nardia scalaris var. botryoidea (R.M.Schust.) Váňa, comb. et stat. nov.

Basionym:-Nardia scalaris subsp. botryoidea R.M.Schust., Hepat. Anthocerotae N. Amer. 2: 862, 1969 (Schuster 1969).

Type:-USA. Tennessee: Smoky Mts., Sevier Co., Charlies Bunion, on Appalachian Trail, 5300-5375 feet, 21 June 1960, R.M. Schuster 45305 (with a few mature capsules) (holotype F-1767552).

\section{References}

Amakawa, T. (1957) Notes on Japanese Hepaticae (3). Journal of Japanese Botany [Shokubutsu kenkyu zasshi] 32: $34-41$.

Amakawa, T. (1959) Family Jungermanniaceae of Japan. I. Journal of the Hattori Botanical Laboratory 21: 248-291.

De Notaris, G. (1858 “1859”) Appunti per un nuovo censimento delle epatiche italiane. Memorie della reale accademia delle scienze di Torino, serie 2 18: 457-498.

De Roo, R.T., Hedderson, T.A. \& Söderström, L. (2007) Molecular insights into the phylogeny of the leafy liverwort family Lophoziaceae Cavers. Taxon 56: 301-314.

Dumortier, B.C. (1831) Sylloge Jungermannidearum Europae indigenarum, earum genera et species systematice complectens. J. casterman, Tournay, 100 pp. http://dx.doi.org/10.5962/bhl.title.22343

Dumortier, B.C. (1835) Recueil d'Observations sur les Jungermanniacées. I. Révision des genres. J.-A. Blanquart, Tournay, $27 \mathrm{pp}$.

Gray, S.F. (1821) Natural Arrangement of British Plants. Vol. I. London, 824 pp.

Kaalaas, B. (1893) Levermosernes udbredelse i Norge. Nyt Magazin for Naturvidenskaberne 33: 1-490.

Konstantinova, N.A. \& Vilnet, A.A. (2010 "2009") New taxa and new combinations in Jungermanniales. Arctoa 18: $65-67$.

Lindberg, S.O. (1874) Manipulus muscorum secundus. Notiser ur Sällskapets pro Fauna et Flora Fennica Förhandlingar 13: 353-417.

Linnaeus, C. (1753) Species Plantarum, ed. 1. Impensis Laurentii Salvii, Holmiae [Stockholm], 1200 pp.

Mitten, W (1865) The "Bryologia" of the survey of the 48th parallel of latitude. Journal of the Linnean Society. Botany 8: $12-55$.

Schuster, R.M. (1969) The Hepaticae and Anthocerotae of North America. vol. II. Columbia University Press, New York, $1062 \mathrm{pp}$.

Söderström, L. Hagborg, A. \& von Konrat, M. (2012) Notes on Early Land Plants Today. Phytotaxa 65: 41-42.

Váňa, J. \& Long, D.G. (2009) Jungermanniaceae of the Sino-Himalayan region. Nova Hedwigia 89: 485-517. http:// dx.doi.org/10.1127/0029-5035/2009/0089-0485

Vilnet, A.A., Konstantinova, N.A. \& Troitsky, A.V. (2011“2010”) Molecular insight on phylogeny and systematics of the Lophoziaceae, Scapaniaceae, Gymnomitriaceae and Jungermanniaceae. Arctoa 19: 31-50. 